\title{
Research Training as Occupational Socialization: Doing Research and Becoming Researchers
}

\author{
Anne Cusick ${ }^{1}$ \\ ${ }^{1}$ School of Health and Society, Faculty of Social Sciences, University of Wollongong; Illawara Health \& \\ Medical Research Institute, Wollongong, Australia \\ Correspondence: Anne Cusick, Faculty of Social Sciences, University of Wollongong, Wollongong, NSW, 2522, \\ Australia. Tel: 61-2-4239-2305. E-mail: acusick@uow.edu.au
}

\author{
Received: September 19, 2014 Accepted: October 29, 2014 Online Published: December 20, 2014 \\ doi:10.5539/ass.v11n2p252 URL: http://dx.doi.org/10.5539/ass.v11n2p252
}

\begin{abstract}
Social science research training is de-facto occupational socialisation to researcher-roles. To do research, trainees need to develop and demonstrate advanced scholarship that complies with disciplinary norms and perform tasks to pre-determined standards. Functionalist approaches to occupational socialization underpin the performative and standardised approach to research training common in universities. But there is more to research training than doing research. If truly successful, trainees will become researchers. They will take on the researcher-role and make it their own. Interpretive approaches to occupational socialization help illuminate intra-and inter-personal dimensions of role-taking and role-making, however this approach is rarely used to inform research training strategies. Occasional scholarship reveals ad-hoc application on interpretive approaches to research trainee experience (e.g., "the journey") supervisor experience (e.g., "emotional burden of supervision"), research training methods such as peer-learning (e.g., informal or fabricated groups, research micro-climates), or research training pedagogy (e.g., collaborative learning, co-production). Recently, interpretive approaches have been used to inform career-planning strategies for PhD graduates (e.g., "Vitae") but this is yet to systematically inform institutional strategies for research-training. To more effectively and efficiently facilitate researcher-role development, research training should consider occupational socialization as an organizing framework, and utilize performative and interpretive approaches to role development.
\end{abstract}

Keywords: social psychology, role theory, functionalist, interpretivist, career development

\section{Introduction}

There is overwhelming evidence that the interplay of personal factors and organisational environments can enhance or impede research productivity. Over 40 years ago, Pelz and Andrews $(1966 ; 1976)$ argued that performance of scientists in research and development organisations was affected by individual motivation, group structure and organizational processes. Innumerable government and non-government organisations have used combinations of these factors over many years to direct, measure and resource research performance with varying success. Prerequisite to any research management strategy is having researchers to manage. Research training has thus become a particular concern of research management, and a recent area of focussed scholarship (Evans, 2011a, b).

Research trainees in postgraduate or doctoral programs develop knowledge and skills at an advanced level. As doctoral graduates they are expected to produce original work that adds to the discipline. They should have the capacity to conduct independent research reflecting research norms of their specialty. The many years of undergraduate and post-graduate education completed by doctoral graduates are de-facto, a long and arduous period of socialisation to the professional role of "researcher" (Antony, 2002).

\section{Occupational Socialization to Researcher Roles}

Socialisation involves learning roles so that individuals can adjust to their environment (Burrell \& Morgan, 1979; Zeichner \& Gore, 1990). Occupational socialization is a conceptual framework that has received meagre attention in the research training literature. Socialization to academic norms (Weidman \& Stein, 2003), to development of researcher identity (Crossouard, 2013; Crossouard \& Pryor, 2009) in research training are relatively recent considerations; although they have been previously considered in relation to practitioner (e.g., 
Cusick, 2000, 2001; Watts, 2009), doctoral research practice in professional-service fields such as sport pedagogy (Lee, 2010), and post-PhD professional research roles (e.g., Åkerlind , 2005, 2008; Pelz \& Andrews, 1976).

There are five major approaches to role theory-functional, symbolic interactionist, structural, organizational and cognitive (Biddle, 1986). Two dominate occupational socialization literature (Burrell \& Morgan, 1979; Merton, 1957; Zeichner \& Gore, 1990): functionalist (derived from Parsons, 1951; see also Jeffrey \& Troman, 2014) and interpretive (derived from Mead, 1934; see also Stryker \& Vryden, 2003, McCall, 2013). The functionalist approach has strengths, but there are limitations; first because the focus is on measurable behavior, conformity with current practice and thus inherent stability of social systems. Second because the burden for role development is one carried by trainees who need to adopt and adapt themselves to surrounding social systems, the personal demands of "normalizing" can be considerable. In role theory, these limitations have led to functionalist perspectives being discredited as reasonable explanations for role expectancy and valorization (Lemay, 1999); however functionalism persists as one of two dominant approaches to occupational socialization (Zeichner \& Gore, 1990) and to role theory as applied to education, research and career training (Jeffrey \& Troman, 2014). The alternative approach to occupational socialisation is the interpretive or social constructivist approach to role and career development (Burrell \& Morgan, 1979; Becker, Geer, Hughes, \& Strauss, 1961; Zeichner \& Gore, 1990). This too has strengths and weaknesses: strength is the way in which roles are constructed to reflect individual meanings and unique social contexts, making them relevant, meaningful and enduring for stakeholders. A weakness is that the rich understanding of individual experience does not account for the disciplinary knowledge and skills required for the researcher role; research training cannot just reflect individual priorities and purposes. Research knowledge and skill development must to reflect socio-cultural expectations so that graduates can fulfill occupational requirements that involve high levels of autonomy, public trust and management of potential risk.

Functionalist and interpretive approaches to occupational socialisation are not incompatible. They can complement each other, ensuring that occupations have people in them who can not only function competently but who personally value the role as meaningful. Since the goal of research training is the development of individual researchers, who are personally confident and professionally competent in this most complex of careers, a more balanced approach to occupational socialisation is recommended and explored here. Effective research training not only enables trainees to meet the cultural-prescriptions of their discipline, it also supports trainees in role-taking and role-making processes that build their unique identity as researchers.

\section{Functionalist Approaches to Research Training}

Although research training is directed towards the development of people-as-researchers, most research training programs focus on generic and specialised skill acquisition (Akerlind, 2008; Bromley, Boran, \& Myddelton, 2007; Evans, 2011a, b; Hinchcliffe, Bromley, \& Hutchinson, 2007). This reflects a functionalist approach to occupational socialization. Research training using this approach has been described as a "performative" (Taylor, 2011) or "provisionist" (Boud \& Lee, 2005). Here, there is a focus on demonstrating a narrow band of observable and measurable attributes as inputs (e.g. discipline base, level of qualification), processes (e.g. Effort and activity as shown in candidature milestones) and outputs (thesis, publications) (e.g., Braxton \& Toombs, 1982). Conformity and adherence to external rules, deadlines and predetermined standards is core to functionalist approaches to occupational socialisation (Burrell \& Morgan, 1979; Zeichner \& Gore, 1990). The person changes in response to the social environment-thus the functionalist approach seeks to facilitate a "smooth change of absolute personal qualities" (Wentworth, 1980, p. 52).

Functionalist approaches to occupational socialisation and resultant performative approaches to research training, mean institutions can standardize recruitment, training, and examination requirements. The functionalist approach has been identified to be the dominant pedagogical model for research training (Boud \& Lee, 2005).

Functionalist approaches assume trainees will comply, perform and complete according to plan. They assume research training and research training organinsations are predictable, efficient and effective. This is patently not the case-research training takes place in organisations that are unpredictable, complex, constantly evolving, and sometimes chaotic. But the sociology of research training organisations and a critical evaluation of research training environments are beyond the scope of this paper. Suffice to say that policy drivers linking enrolments and completions to performance-based funding exemplify and reinforce the dominance of functionalist approaches to research training (Neumann, 2007). If all goes well, trainees are selected, inducted, progressed and completed to a high standard on time and on budget. This helps assure continuity in the discipline, research program or institution. 
Traditionally, one-to-one supervision has been adopted as the primary research training strategy in functionalist approaches to occupational socialization. Supervisors or supervising teams will induct candidates, "teach" the attitudes, knowledge and skills required to "do research" and the research trainees will "do it". Many institutions have adopted quality supervision frameworks to support this (e.g., Kiley, 2011). Of course students need to demonstrate individual originality to meet requirements of doctoral research, but this individuality is limited to knowdge produced within discipline norms and existing institutional procedures. A successful research training program will thus result in individuals who: are socially integrated in the discipline, specialty and research team; have a sense of solidarity with other researchers and the field; feel their needs have been satisfied; and will be recognised as 'researchers' by their colleagues, discipline and prospective employers. The more efficiently this can be achieved, the smoother the "absolute change" of the individual the better the research training program.

While there are strengths to this approach, construction of individual roles can be neglected (Lee, 2008; Stelma \& Fay, 2012). This is problematic because there is more to being a researcher than just 'doing research'. Research training is a long, arduous process fraught with risk. A high degree of intentionality is needed to sustain trainees during researcher role development (Stemla \& Fay, 2012). The research training system, when built around functionalist approaches to socialization, neglects personal learning (Lindén, Ohlin, \& Brodin, 2013) instead emphasizing research related tasks. Unsurprisingly, social isolation is a major challenge for trainees (Hortsmanshof \& Conrad, 2003; Janta, Lugosi, \& Brown, 2012). Functional approaches to research training have also been criticized for using summative rather than formative assessment further reinforcing the unimportance of personal learning: summative assessment in research training is focussed on outputs while formative facilitates reflection on emerging research identities (Crossouard \& Pryor, 2008).

\section{Interpretive Approaches to Research Training}

Interpretive, representational or social constructivist approaches assume research trainees actively construct the research role in their lives, building a research identity through day-to-day activities and interactions (McAlpine, Jazvac-Martek, \& Hopwood, 2009). Here, the focus is on social construction of the self (Callero, 2003). The experience of research training is "a personal journey" (Hughes \& Tight, 2013; Stubb, Phyhalto, \& Lonka, 2012) where students change as people (Wood, 2006) and develop conceptions of the self, the PhD and knowledge and outcomes of their research (Pitcher, 2010). Research trainees "become" scientists (Louis, Holdsworth, \& Campbell, 2007), constructing personal narratives around their research experience (Taylor, 2010) and through supervisory relationships that may involve co-learning and co-production of new knowledge (Trafford, 2012). In doing so they build unique research identities (Murakami-Ramalho, Militello, \& Piert, 2013) producing new knowledge in changing social and cultural contexts (Crossouard, 2013). Good research training using an interpretive approach will acknowledge and support the construction of a research identity (Fenge, 2012) and an expanded supervisor role (Lee, 2008, 2012, 2014).

One of the challenges for researcher role development using an interpretive perspective is knowing how to harness and facilitate potent elements of the process in institutional strategies. The next section of this paper describes what research trainee role development "looks like" from an interpretive perspective. In doing so, elements of the social construction of roles are identified and the iterative process that is the research trainee 'journey' is explored. A later section gives three examples of ways in which interpretive approaches to research training have been applied in post-PhD career planning, scholarship relating to doctoral supervision and use of peer and research groups to support role development of trainees.

\subsection{The Personal Biography}

Interpretive approaches to role development assume individuals build a sense of identity and meaning about themselves, their world and their place in it (Stryker \& Vryan, 2003). Broadly, researcher role development is conceived as a loose iterative process commencing with: (a) a person identifying a particular role as desirable; (b) engaging in activities and building relationships to develop the role in their lives; and (c) evaluating whether or not role acquisition was successful or a good life "fit" using feedback from their interactions with others and measures of career achievement (e.g., Cusick, 2000, 2001). Although there is some directionality in role development, it is not a linear process because individuals go back and forth reflecting on their evolving identity in changing social contexts. It takes many years and often over a decade, for someone to become a researcher. The process begins well before any doctoral training even begins.

Every trainee brings a "personal biography" with them when they enter formal research training. From an interpretive occupational socialisation point of view, this biography is important because it provides the motivation and meaning behind commitment to the researcher role. Each research trainee has unique circumstances, events and influences that pre-dispose or provoke them to consider a social science researcher 
role and decide it was worth pursuing. Some of the most important elements in this biography are research role models.

\subsection{Researcher Role Models}

A person won't consider building their own identity in relation to a role unless they have been exposed to it. Exposure can be direct, for example observing real social scientists at work as family members in social science occupations, teachers in relevant disciplines, college professors or industry social scientists. Or it can be via other more indirect means. In the past it may have been through public lectures by social scientists, inspiring books about scientific discoveries and the people involved, the people involved and how discoveries helped individuals and society. More recently, media is awash with social science researcher role models: the "cool-school" public intellectual bringing social science to talk-back radio and social media; the forensic "who-done-it" television social scientist using their advanced understanding of human behaviour, social trends, qualitative and quantitative findings to profile the offender and solve the case; the researcher in social science-gone-wrong block-busters of future worlds; "sleek-geek" comedies of social scientists and their friends; and podcasts or documentaries where social science researchers shine a light on complex problems.

By the time a candidate is accepted for research training, he or she has usually been exposed to many imagined and some "real" social science research roles models. Typically real social science researchers are encountered at university in the undergraduate years, with exposure is on an increasingly personal scale: introductory large cohort social science classes across different disciplines in first year, to smaller speciality classes in senior undergraduate years and then small group and one-on-one mentoring in discipline-specific research preparation programs. Supervisors have been found to be the most important role models (Halberg, Hjort, Londahl et al., 2012). With increasing exposure the depth and breadth of role model alternatives becomes richer. Trainees develop increasingly complex expectations about what they themselves might look like, what they might do and achieve as "social scientists". They start to personally identify with the social science researcher role.

\subsection{Research Role Identification}

Social science researcher role models have expanded from stereotypical Anglo-American tweed-jacket-pipe-smoking-males to a fabulous range of diverse alternatives. The increasing diversity of social science researcher role models means more people are more likely to consider the social science researcher role as one that is relevant to them. Each role model offers identity alternatives that can feed into the individual's emerging identity.

Role identification is a process. Some people consciously consider their role options; indeed they might be able to recall a time when they "decided" to become a social scientist-in general or in relation to a specific disciplinary role such as psychologist, sociologist, and economist and so on. For others, role identification is more chaotic and less conscious. They may be attracted by images on television, "turned off" by real social scientists they meet, inspired by social scientists in the public domain, and even as they are attracted to the researcher role they may wonder if alternative role identities would better suit them. Even though role identification requires intention, the complexity of the process may mean it feels more like they "fell into" social science research, or they were "forced into it" by others around them, or it "just happened". Regardless of paths taken towards researcher roles, personal biography and role identification will influence expectations about behaviours needed to "become a social scientist" and what it means to "be a researcher".

\subsection{Research Role Acquisition}

Trainees tend to adopt the behavioural norms of social science groups they aspire to join. They need to learn what new group behaviours and values are required and they need to demonstrate them to show they have "what it takes" to be a potential member. They need to calibrate what they do, how they do it and to what standard according to group norms. They need to evaluate how well they think they "fit in" over time; and as their own capacity changes, how well the group continues to "fit them". The most important role model relationship in research role acquisition is that of the student and the supervisor (Lee, 2008, 2012, 2014).

Most trainees will make an effort to become accepted members of their research training team and the team's related networks. Often this is by mirroring the behaviours of a role model or combination of role models in the group. When the biographical gap between trainee and role models is great-for example through gender, cultural and linguistic background, lifestyle or undergraduate discipline differences-this can make role acquisition harder because target role-model behaviours need to be interpreted and adapted by the role aspirant before they can be tried out by the trainee. Sometimes a trainee with research potential does not "work out" because they cannot negotiate the behavioural norms and values of a research team. If they have the necessary intelligence and 
technical skills, it may be due to their difficulty interpreting and individualising the behaviour of the target group. Alternatively, 'working out' may have nothing to do with individual biography, or the range of role models available. Instead it may relate to the trainee's social skills, self-awareness and their ability to adapt to group norms.

\subsection{Role Validation}

How do research trainees know if their role acquisition has been successful? Ultimately it will be when they exit the role with completed dissertations and their research degrees in hand. But along the way they need to know if the identity they are building is one that is personally meaningful and right for the research environment around them. Role validation, like role identification and acquisition, occurs through social interactions.

When research trainees feel like they belong, when they are trusted to orientate and socialise new trainees to the team, when they have their expertise affirmed at seminar presentations, conferences and in team discussions, and when they are encouraged to share personal perspectives-these social interactions provide evidence of role validation. Role validation is an ongoing process linked to continuous role acquisition. Successful research trainees will always be faced with new role acquisition challenges if they identify with new role models or want to move into other social science groups. Trainees are constantly engaged in building capacity for their research futures (Sinclair, Barnacle, \& Cuthbert, 2013).

The interpretive approach to occupational socialisation emphasises the individuality and intentionality of trainee experience in constructing the research role in their lives. For each research trainee a personal history of previous roles and contexts will have already led them toward selecting the role as desirable. To recap, once research trainees, they will construct the role in their lives by:

- identifying the research role as personally valuable, culturally meaningful and worthy of pursuit

- identifying particular social science researcher role models and creating personally meaningful potential and actual researcher identities;

- developing expectations regarding current and future personal researcher roles and iteratvely revising expectations and meanings to individualize the trainee and researcher role;

- acquiring skills and knowledge regarding technical tasks and cultural norms required of research trainees and negotiating these in the context of emerging and potential individual research-trainee identities;

- revising the conduct of their daily life to enact socio-cultural role norms and construct unique trainee and researcher identities;

- evaluating their emerging identity as both research-trainees and future researchers, weighing up the trainee role in the context of other current and future life roles.

If interpretive approaches to research training have merit, the challenge for institutions and social science research training programs is how best to embed these when funding, accountability and reporting processes reflect functionalist approaches to meeting structural demands.

\section{Institutionalizing Interpretive Approaches?}

Practically, how can interpretive approaches to occupational socialisation and career development become institutionalized? In the first instance, existing research training social structures could be leveraged to explicitly address elements of the research role development. These structures include supervisor-student relationships, and use of peers.

\subsection{Researcher Career Development}

A field of occupational socialisation that has grappled with the functionalist-interpretive dichotomy is career development. Career development of post-PhD researchers has attracted considerable scholarly and policy attention. Although $\mathrm{PhD}$ graduates have highly specialized skills and knowledge, they still need to construct research careers (Åkerlind, 2005, 2008). Traditionally, career development has focussed on enhancing or expanding task performance; but for highly skilled research graduates task performance is not the issue (Lee, Gower, Ellis, \& Bellantuonoa, 2010). Instead they face personal questions that can only be answered in a social context: "who/what am I now without my team/ field/ supervisor?"; "where do I fit/ who-with/ how do others see me?"; "how can I join the networks and teams I need to do research?" Further skill development is not the priority. These questions reflect core elements of an interpretive approach to occupational socialisation. Interpretive approaches have thus been recommended to inform career development approaches for post-PhD novice researchers (Bray \& Boon, 2011; McMahon \& Patton, 2006). Why not for pre-graduation PhD candidates as well? 
The "UK Vitae" (Vitae, 2014) initiative provides an example of a post-PhD career development strategy that could be adapted to structure and guide social interactions of research trainees with their supervisors, key role models and group members. The Vitae approach was developed to address a problem identified by the United Kingdom problem in relation to early career research role development.

The Vitae approach uses structured person-centred, reflective social processes to help $\mathrm{PhD}$ graduates construct a career direction and plan. Mentors and new researchers can use the Researcher Development Framework (RDF) (Vitae, 2014) and the RDF Professional Development Planner (PDP) (Bray \& Boon, 2011; Vitae, 2014). These tools provide structured interview methods for reflective conversations, and standards against which researchers can compare their own attributes and capacities. Self-assessment and benchmark standards in the RDF and PDP are used as a basis for social interaction with mentors and colleagues. The approach has been found to be workable, meaningful and useful in identifying career development needs and strategies, and effective in relation to setting and achieving personal learning outcomes (Bray \& Boon, 2011). This approach could be adapted for research trainees to help structure supervisor-student interactions to complement existing performance focussed strategies.

\subsection{Research Supervision}

The longest surviving institutional strategy for research training-the supervisor-student relationship-is also one that is already embedded, but one that has only recently attracted analysis and recommendations from action from an interpretive perspective. As yet there are no nation-wide or high level institutional interventions (equivalent in scope, scale and application to the Vitae approach for example), but there are increasing examples of research that illuminate issues in supervision and potential ways forward in this oldest of research training stratgies. Some examples are now given to demonstrate the scope of enquiry. Lee $(2008,2012,2014)$ identified supervisory relationships encompass not only functional elements, but those of enculturation, critical thinking and emancipation and quality relationships. Ngyuen (2010) suggested use of the sociocultural perspective to explore scaffolding of the research training experience. Bruce and Stoodley (2008) and Trafford (2012) suggested supervision and supervisory relationships were being reframed as pedagogy or teaching and learning practice. Trafford in particular sound communication skills were critical for the student-supervisor relationship with less emphasis on discipline-centric knowledge and skill co-learning and co-production of knowledge a feature. Halse (2011) identified that it is not only students but supervisors who undergo role development-they "become supervisors". Wisker (2012) explored and advised what makes a "good supervisor". Wisker and Robinson (2012) highlighted the critical importance of supervisor experience in acquiring and losing doctoral students, particularly those who are "orphans" of previous failed or finished supervisory relationships. Roed (2012) found that supervision, far from being just about performance and task achievement, is "emotional labour" for supervisors-"a labour of love". It is clear from these examples that supervision, as the primary strategy for research training has an increasing body of evidence and recommendations for practice that embrace the interpretivist approach to researcher role development.

\subsection{Peer Support}

Peer support groups are already used in research training environment through supervisor, institution or student initiated peer support groups (Cusick, Camer, Stamenkovic, \& Zacagnini, 2014; Hortsmanshof \& Conrad, 2003; Pilbeam, Lloyd-Jones, \& Denyer, 2013), and consideration of research groups as "micro-climates" that can facilitate or impede research trainee development particularly that of international students (Walsh, 2010). While interpretive assumptions may not have been the foundation for their development, peer groups are institutionalized mechanisms that could be explicitly used to promote the person-centred social exchange necessary for reflective role development. Peer support has been shown to enrich the research training experience because it allows opportunities for trainees to "engage reflexively with discursive processes around their identity as researching professionals" (Fenge, 2012, p. 410). Peers provide the social environment needed for identity construction (Taylor, 2011), shared understandings regarding the research student experience (Deem \& Brehony, 2000), and experience of the collaborative and peer-review process of research (Hortsmanshof \& Conrad, 2003). Extending their remit from induction and skill training to explicit support for social reflection on emerging research identities is an achievable way to institutionalise interpretive approaches.

\section{The Way Forward}

Research training is a long and complex process of occupational socialisation. Our training must ensure that graduates can not only do research, they become researchers. To achieve this aim, research training needs to provide opportunities for technical and personal learning, so that the complex task of navigating researcher role development is supported. Functionalist and interpretive approaches to occupational socialisation together provide conceptual frameworks that can inform social science research training strategies of institutions and 
supervisors. The challenge now is to see how research training institutions can respond to an occupational socialization approach to research training.

\section{References}

Åkerlind, G. S. (2005). Postdoctoral researchers: Roles, functions and career prospects. Higher Education Research and Development, 24, 21-40. http://dx.doi.org/10.1080/0729436052000318550

Åkerlind, G. S. (2008). Growing and developing as a university researcher. Higher Education, 55, 241-254. http://dx.doi.org/10.1007/s10734-007-9052-x

Antony, J. S. (2002). Reexamining doctoral student socialization and professional development: Moving beyond the congruence and assimilation orientation. In J. C. Smart, \& W. G. Tierney (Eds.), Higher Education: Handbook of Theory and Research (Vol. XVII, pp. 349-380). Agathon Press, New York. http://dx.doi.org/10. 1007/978-94-010-0245-5_8

Austin, A. E. (2002). Preparing the next generation of faculty: graduate school as socialization to the academic career. The Journal of Higher Education, 73, 94-122. http://dx.doi.org/10.1353/jhe.2002.0001

Becker, H. S., Geer, B., Hughes, E. C., \& Strauss, A. L. (1961). Boys in white. Chicago: University of Chicago press.

Biddle, B. (1986). Recent Development in Role Theory. Annual Review of Sociology, 12, 67-1292. http://dx. doi.org/10.1146/annurev.so.12.080186.000435

Boud, D., \& Lee, A. (2005). 'Peer learning' as pedagogic discourse for research education. Studies in Higher Education, 30, 501-516. http://dx.doi.org/10.1080/03075070500249138

Braxton, J. M., \& Toombs, W. (1982). Faculty uses of doctoral training: Consideration of a technique for the differentiation of scholarly effort from research activity. Research in Higher Education, 16, 265-282. http://dx.doi.org/10.1007/BF00973587

Bray, R., \& Boon, S. (2011). Towards a framework for research career development: An evaluation of the UK's vitae researcher development framework. International Journal for Researcher Development, 2, 99-116. http://dx.doi.org/10.1108/17597511111212709

Bromley, A. P., Boran, J. R., \& Myddelton, W. A. (2007). Investigating the baseline skills of research students using a competency-based self-assessment method. Active Learning in Higher Education, 8, 117-137. http://dx.doi.org/10.1177/1469787407077992

Bruce, C., \& Stoodley, I. (2009). Towards pedagogy of RHD supervision in the technology disciplines: Talking about supervision as teaching and learning practice: In technology and engineering. ALTC Fellowship, Queensland University of Technology. Retrieved October 10, 2014, from http//:www.altcexchange.edu.au/

Burrell, G., \& Morgan, G. (1979). Sociological paradigms and organizational analysis. London: Heinemann.

Callero, P. L. (2003). The sociology of the self. Annual Review of Sociology, 29, 115-133. http://dx.doi.org/10. 1146/annurev.soc.29.010202.100057

Crossouard, B. (2013). Conceptualising doctoral researcher training through Bernstein's theoretical frameworks. International Journal for Researcher Development, 4, 72-85. http://dx.doi.org/10.1108/IJRD-05-2013-0007

Crossouard, B., \& Pryor, J. (2008). Becoming researchers: A sociocultural perspective on assessment, learning and the construction of identity in a professional doctorate. Pedagogy, Culture and Society, 16, 221-237. http://dx.doi.org/10.1080/14681360802346614

Cusick, A. (2000). Practitioner-researchers in occupational therapy. Australian Occupational Therapy Journal, 47, 11-27. http://dx.doi.org/10.1046/j.1440-1630.2000.00195.x

Cusick, A. (2001). The experience of clinician-researchers in occupational therapy. American Journal of Occupational Therapy, 55, 9-18. http://dx.doi.org/10.5014/ajot.55.1.9

Cusick, A., Camer, D., Stamenkovic, A., \& Zacagnini, M. (2014). Supplementary Instruction for Research Trainees Using a Peer Assisted Study Session Methodology, Submitted 25.10.14, In review, Journal of Peer Learning, pre-review version available Faculty of Social Sciences, University of Wollongong, Australia.

Deem, R., \& Brehony, K. (2000). Doctoral students' access to research cultures-are some more unequal than others? Studies in Higher Education, 25, 149-165. http://dx.doi.org/10.1080/713696138

Evans, L. (2011a). What research administrators need to know about researcher development: Towards a new 
conceptual model. Journal of Research Administration, 42, 15-37.

Evans, L. (2011b). The scholarship of researcher development: Mapping the terrain and pushing back boundaries. International Journal for Researcher Development, 2, 75-98. http://dx.doi.org/10.1108/17597511111212691

Fenge, L. (2012). Enhancing the doctoral journey: The role of group supervision in supporting collaborative learning and creativity. Studies in Higher Education, 37, 401-414. http://dx.doi.org/10.1080/03075079.2010. 520697

Hallberg, H., Hjort, V., Löndahl, J., Magnusson, M., \& Törmänen, M. (2012). Supervisor roles and role models. Project Report, Lund University. Retrieved from http://www.solid.lth.se/fileadmin/hallfasthetslara/staff/ hlhh/hlhh_undervisning/Hallberg_etal_2012_Docentkurs.pdf

Halse, C. (2011). "Becoming a supervisor": The impact of doctorial supervision on supervisors learning. Studies in Higher Education, 36, 557-570. http://dx.doi.org/10.1080/03075079.2011.594593

Hinchcliffe, R., Bromley, A., \& Hutchinson, S. (2007). Skills training in research degree programmes: Politics and practice. Berkshire England: Open University Press McGraw-Hill Education.

Hortsmanshof, L., \& Conrad, L. (2003). Postgraduate peer support program: Enhancing community. In Learning for an unknown future Proceedings of the $26^{\text {th }}$ HERDSA Annual Conference (pp. 6-9). Christchurch New Zealand. Retrieved from http://www.herdsa.org.au/wp-content/uploads/conference/2003/papers/HERDS A47.pdf

Hughes, C., \& Tight, M. (2013). The metaphors we study by: The doctorate as a journey and/or as work. Higher Education Research \& Development, 32, 765-775. http://dx.doi.org/10.1080/07294360.2013.777031

Janta, H., Lugosi, P., \& Brown, L. (2012). Coping with loneliness: A netographic study of doctoral students. Journal of Further and Higher Education, 38, 553-571. http://dx.doi.org/10.1080/0309877X.2012.726972

Jeffrey, B., \& Troman, G. (Eds.) (2014). Performativity in UK education: Ethnographic cases of its effects, agency and reconstructions. Kobo-eReader E \& E Publishing; ISBN: 9780956900760.

Kiley, M. (2011). Developments in research supervisor training: Causes and responses. Studies in Higher Education, 36, 585-599. http://dx.doi.org/10.1080/03075079.2011.594595

Lee, A. (2008). How is doctoral research students supervised? Studies in Higher Education 33, 267-281. http://dx.doi.org/10.1080/03075070802049202

Lee, A. (2012). Successful research supervision: Advising students doing research. Milton Park UK, Routeledge Taylor \& Francis Group.

Lee, A. (2014). Researcher development: So, do we need supervisors anymore? Standing Conference on Academic Practice at the University of Warwick. Retrieved October 30, 2014, from http://www.drannelee.wordpress. com

Lee, H. (2010). Impact of occupational socialization on the perspectives and practices of sport pedagogy doctoral students. Thesis Master of Arts Kinesiology, University of Alabama, USA, Retrieved October 10, 2014, from http://acumen.lib.ua.edu/content/u0015/0000001/0000448/u0015_0000001_0000448.pdf

Lee, L., Gowers, I., Ellis, L., \& Bellantuonoa, I. (2010). Well rounded postdoctoral researchers with initiative, who are not always 'tied to the bench' are more successful academically. International Journal for Researcher Development, 1, 269-289. http://dx.doi.org/10.1108/1759751X201100021

Lemay, R. A. (1999). Roles, identities and expectancies: Positive contributions to normalization and social role valorization, Chapter 10. In R. J. Flynn, \& R. A. Lemay (Eds.), A quarter century of normalisation and social role valorization: Evolution and impact (pp. 219-240). Ottowa, Canada: University of Ottowa Press.

Lindén, J. M., Ohlin, M., \& Brodin, E. M. (2013). Mentorship, supervision and learning experience in PhD education. Studies in Higher Education, 38, 639-662. http://dx.doi.org/10.1080/03075079.2011.596526

McAlpine, L., Jazvac-Martek, M., \& Hopwood, N. (2009). Doctoral student experience in education: Activities and difficulties influencing identity development. International Journal for Researcher Development, 1, 97-109. http://dx.doi.org/10.1108/1759751X201100007

McCall, G. J. (2013). Interactionist perspectives in social psychology. In J. DeLamater, \& A. Ward (Eds.), Handbook of Social Psychology (2nd ed.). New Work, Springer Science + Business Media.

McMahon, M., \& Patton, W. (Eds.) (2006). Career Counselling: Constructivist Approaches. London: Routledge. 
Mead, G. H. (1934). Mind, self and society. Chicago: Chicago University Press.

Merton, R. L. (1957). Social Theory and Social Structure. The Free Press, New York.

Murakami-Ramalho, E., Militello, M., \& Piert, J. (2013). A view from within: How doctoral students in educational administration develop research knowledge and identity. Studies in Higher Education, 38, 256-271. http://dx.doi.org/10.1080/03075079.2011.578738

Neumann, R. (2007). Policy and practice in doctoral education. Studies in Higher Education, 32, 459-473. Nguyen, M. H. (2012). The Potential for Vygotskian Sociocultural Perspective in Researching Researcher Development. Asian Social Science, 8(15). http://dx.doi.org/10.1080/03075070701476134

Parsons, T. (1951). The social system. New York: The Free press of Glencoe.

Pelz, D. C., \& Andrews, F. M. (1966). Scientists in organizations: Productive climates for research and development. New Jersey: John Wiley and Sons Inc.

Pelz, D. C., \& Andrews, F. M. (1976). Scientists in organizations: Productive climates for research and development (Revised ed.). Institute for Social Research, the University of Michigan, Ann Arbor, Michigan, USA.

Pilbeam, C., Lloyd-Jones, G., \& Denyer, D. (2013). Leveraging value in doctoral student networks through social capital. Studies in Higher Education, 38, 1472-1489. http://dx.doi.org/10.1080/03075079.2011.636800

Pitcher, R. (2010). The Self in Research and Other Matters: A Study of Doctoral Students' Conceptions. International Journal for Researcher Development, 1, 248-256. http://dx.doi.org/10.1108/1759751X2011 00018

Roed, J. (2012). Labour of love: Emotions and identities in doctoral supervision. Doctor of Philosophy Thesis, University of Sussex, Sussex research Online. Retrieved from http//:sro.sussex.ac.uk/

Sinclair, J., Barnacle, R., \& Cuthbert, D. (2013). How the doctorate contributes to the formation of active researchers: What the research tells us. Studies in Higher Education.

Stelma, J., \& Fay, R. (2012). Intentionality and developing researcher competence on a UK master's course: An ecological perspective on research education. Studies in Higher Education, 39, 517-533. http://dx.doi.org /10.1080/03075079.2012.709489

Stryker, S., \& Vryan, K. D. (2003). The symbolic interactionist frame. Chapter 1. In J. Delemater (Ed.), Handbook of Social Psychology (pp. 3-28). New York, Kluwer Academic/Plenum Publishers.

Stubb, J., Phyhalto, K., \& Lonka, K. (2012). Conceptions of research: The doctoral student experience in three domains. Studies in Higher Education, 39, 251-264. http://dx.doi.org/10.1080/03075079.2011.651449

Taylor, C. A. (2011). More than meets the eye: The use of videonarratives to facilitate doctoral students' reflexivity on their doctoral journeys. Studies in Higher Education, 36, 441-458. http://dx.doi.org/10.1080 /03075071003714115

Taylor, C., Downs, Y., Chikwa, G., \& Baker, R. (2011). I did it my way: Voice, visuality and identity in doctoral students' reflexive videonarratives on their doctoral research journeys. International Journal of Research and Method in Education, 34(2), 193-210. http://dx.doi.org/10.1080/1743727X.2011.578818

Trafford, J. A. (2012). Research supervision practices in New Zealand postgraduate geography: Capacity-capability potentialities: PhD Dissertation. The University of Aukland, New Zealand. Retrieved from http://researchspace.aukland.ac.nz

Vitae. (2014). Realising the potential of researchers, Researcher Development Framework. Retrieved September 9, 2014, from https://www.vitae.ac.uk/

Walsh, E. (2010). A model of research group microclimate: Environmental and cultural factors affecting the experiences of overseas research students in the UK. Studies in Higher Education, 35, 545-560. http://dx. doi.org/10.1080/03075070903243092

Watts, J. H. (2009). From professional to PhD student: Challenges of status transition. Teaching in Higher Education, 14, 687-691. http://dx.doi.org/10.1080/13562510903315357

Weidman, J. C., \& Stein, E. L. (2003). Socialization of doctoral students to academic norms. Research in Higher Education, 44, 641-656. http://dx.doi.org/10.1023/A:1026123508335

Wentworth, W. M. (1980). Context and understanding: An enquiry into socialization theory. New York: Elsevier 
North Holland.

Wisker, G. (2012). The good supervisor. New York, Palgrave Macmillan.

Wisker, G., \& Robinson, G. (2012). Picking up the pieces: Supervisors and doctoral "orphans". International Journal for Researcher Development, 3, 139-153. http://dx.doi.org/10.1108/17597511311316982

Wood, K. (2006). Changing as a person: The experience of learning to research in the social sciences. Higher Education Research \& Development, 25, 53-66. http://dx.doi.org/10.1080/13600800500453162

Zeichner, K. M., \& Gore, J. M. (1990). Teacher Socialization. In W. R. Houston (Ed.), Handbook of research on teacher education (pp. 329-348). New York: MacMillan.

\section{Copyrights}

Copyright for this article is retained by the author(s), with first publication rights granted to the journal.

This is an open-access article distributed under the terms and conditions of the Creative Commons Attribution license (http://creativecommons.org/licenses/by/3.0/). 